Мельничук $\Lambda$. Оригінальна графіка в українських зіьраннях XIX ст. ...

УДК 76:94(477):7.074

DOI https://doi.org/10.24919/2308-4863/34-3-4

Людмила МЕЛЬНИЧУК,

orcid.org/0000-0002-1504-1425

кандидат мистецтвознавства, доцент,

доиент кафедри теорії і історії мистеитв

Харківської державної академії дизайну і мистеитв

(Харків, Україна) ludmel11@ukr.net

\title{
ОРИГІНАЛЬНА ГРАФІКА В УКРАЇНСЬКИХ ЗІБРАННЯХ ХІХ СТ. КОЛЕКЦІЯ АРКАДІЯ АЛФЬОРОВА
}

\begin{abstract}
Останніми роками в Україні значно зріс інтерес до вивчення історії приватного колекціонування творів мистецтва, практики колекиіонування, його культурної і соціальної зумовленості, значення в становленні мистецького музейництва. За допомогою музейних документів, каталогів, архівних матеріалів можна встановити шляхи надходження і походження багатьох творів, провести реконструкцію частково втрачених мистецььких колекцій і виявити внесок їхніх власників у розвиток художнього життя в Украӥні.

У статті йдеться про колекиіонерську діяльність Аркадія Алфьорова, слобожсанського землевласника, дослідника гравюри. Його колекиія живопису й графіки надійшла 1873 р. за заповітом до Харківського університету, значно поповнивши зібрання Музею красних мистеццтв і старожитностей. Колекція оригінальної графіки, щзо зберігається нині в Харківському художньому музеї, є однією з найзначніших в Украйні.

Метою дослідження стали аналіз структури колекції оригінальної графіки А. Алфьорова, иляхів поповнення колекції, причин втрат протягом ХХ ст. Виявлено, щчо оригінальна графіка в колекції Алфьорова представлена різними національними школами відповідно до етапів їхнього розвитку. Колекціонер иілеспрямовано збирав твори, щзо презентують різні техніки графічного мистецтва й відомі імена. А. Алфьоров являв собою тип колекціонера-знавия, який невтомно досліджував твори мистецчтва і будував колекцію відповідно до естетичних поглядів часу, певної структури і мети збирання. Він поповнював колекцію, проживаючи за кордоном (у Німеччині), відвідував галереї і аукціони в різних крайнах, був знайомий із мистияли і колекціонерами, щуо вплинуло на його мистецькі уподобання.

Викладені результати дослідження показують колекиіонування як явище в історії мистецтв, розкривають важливу роль благодійників, зокрема А. Алфьорова в поширенні публічних зібрань.
\end{abstract}

Ключові слова: оригінальна графіка, мистецькі зібрання, колекціонування творів мистецтва, Аркадій Алфьоров.

Liudmyla MELNYCHUK, orcid.org/0000-0002-1504-1425

Candidate of Art History, Associate Professor, Associate Professor at the Department of Theory and History of Arts Kharkiv State Academy of Design and Arts (Kharkiv,Ukraine)ludmel11@ukr.net

\section{ORIGINAL GRAPHICS IN UKRAINIAN COLLECTIONS OF THE XIX CENTURY. COLLECTION OF ARKADIY ALFEROV}

In Ukraine interest in studying the history of private collecting of works of art, also as practice of collecting, it's cultural and social conditionality, the importance in the formation of art museology has grown significantly in recent years. With the help of museum documents, catalogs, archival materials it is becomes possible to establish the ways of receipt and origin of many works, to reconstruct partially lost art collections and to determine the contribution of their owners to the development of artistic life in Ukraine.

The article presented the collecting activity of Arkady Alferov, a landlord from Slobozhanshyna, a researcher of engraving. His collection of paintings and graphics was gifted in 1873 by his testament to Kharkiv University, significantly supplemented the collection of the Museum of Fine Arts and Antiquities. The collection of original graphics, now stored in the Kharkiv Art Museum, is one of the most significant in Ukraine.

The aim of this study was to analyze the structure of the collection of original graphics of A. Alferov, ways of replenish the collection, the causes of losses during the twentieth century. It was founded that the original graphics in Alferov's collection are represented by different national schools according to the stages of their development. The collector purposefully collected works which presenting various techniques of graphic art and famous names. A. Alferov is a type of collector-connoisseur who tirelessly researched works of art and built a collection in accordance with the aesthetic 
views of the time, according to a certain structure and purpose of collection. He replenished the collection, living abroad (in Germany), visiting galleries and auctions in various countries, was acquainted with artists and collectors, which influenced his artistic tastes.

The presented results of the research show a collecting as a phenomenon in the history of arts, reveal the important role of philanthropists, in particular A. Alferov, in the dissemination of public collections.

Key words: original graphics, art collections, collecting works of art, Arkady Alferov.

Постановка проблеми. У збиранні, збереженні, популяризації творів мистецтва важливу роль завжди відігравали колекціонери. В Україні, зокрема на Слобожанщині, колекції творів мистецтва активно формуються в XIX ст. Вагомою часткою таких зібрань були твори графіки. Нині такі зібрання зазвичай зберігаються в музеях іє відкритими для дослідників. Утім, зазвичай графіці приділяється все ж менше уваги, ніж живопису. Такі колекції потребують каталогізації і ретельного пошуку відомостей щодо походження і побутування творів, а також реконструкції з урахуванням численних втрат у ХХ ст. Лише склавши цілісну картину можна оцінити внесок українських колекціонерів у створення національної цінності, до якої і належать такі зібрання.

У 1873 р. музей Харківського університету отримав за заповітом Аркадія Алфьорова цінну колекцію, що включала твори живопису і графіки. Чільне місце в ній (як кількісно, так і якісно) належало оригінальній графіці різних європейських шкіл XVI-XIX ст. Ретельний аналіз цієї збірки в колекції Алфьорова, іiі формування, складу, особливостей допомагає виявити важливі аспекти колекціонування як явища художнього життя в Україні, зокрема на Слобожанщині, дає відповіді, як особистість колекціонера, конкретно-історична і мистецька ситуація впливали на колекціонерську практику, мету і ідеї збирачів, а також на той слід, який вони залишили в історії.

Аналіз досліджень. Головним джерелом реконструкції і дослідження колекції оригінальної графіки А. Алфьорова $є$ каталог «Живопис. Акварелі і рисунки», упорядкований зберігачем музею Харківського університету і бібліографом Г. Чириковим, надрукований 1877 р. за пропозицією О. Потебні. У цьому випуску покажчика також є акварелі і рисунки з колекції Алфьорова. Для написання огляду Чириков долучив листи А. Алфьорова, архівні та документальні матеріали.

Перший фахівець-мистецтвознавець Харківського університету С. Рєдін, який з 1896 р. очолював кафедру теорії і історії мистецтв і університетський музей, високо оцінив пожертвування Алфьорова в історичній розвідці «Музей красних мистецтв і старожитностей Імператорського Харківського університету». Цінними в цьому виданні є витяги із записки М. Зарудного про А. Алфьо- рова та цитування 3 листів Алфьорова, що розкривали мету збирання мистецьких творів колекціонером. Ці листи були надруковані в місцевій пресі, але збереглися лише в працях С. Рєдіна.

Високу оцінку приватній колекції Алфьорова i внеску збирача в культурне життя краю дав i видатний український історик Д. Багалій у монументальній праці (спільно 3 Д. Міллером) «Історія міста Харкова за 250 років його існування». Документальну цінність мають світлини колекціонера А. Алфьорова, подані в ювілейному альбомі до сторіччя Харківського університету, а також в окремому додатку до праці Д. Багалія і Д. Міллера.

Дореволюційні путівники по Харкову 1881 р., 1915 р. ознайомлюють із приватними колекціями університетського музею, високо оцінюючи колекції і самі діяння дарувальників, зокрема А. Алфьорова.

Інвентарні книги Української картинної галеpeї (нині - в Харківському художньому музеї) мають відомості про кількісний склад колекції Алфьорова напередодні Другої світової війни, про перерозподіл творів із колекції поміж музеями України після війни.

Цікавий фактологічний матеріал містять публікації мистецтвознавців Харківського художнього музею В. Мизгіної, Т. Прокатової. Розвідки сучасного українського історика О. Алфьорова, нащадка роду Алфьорових, розширюють відомості про родину колекціонера.

Новаторський аналіз такого складного явища, як колекціонування, практики колекціонерської діяльності розглянуті в сучасній монографії польської дослідниці Ренати Таньчук «Мистецтво колекціонування. Колекціонування як форма культуральної активності», що стала теоретичним підгрунтям для написання статті.

Мета статті - виявити особливості колекції оригінальної графіки А. Алфьорова, проаналізувати їі структуру, розглянути практику колекціонерської діяльності А. Алфьорова і розкрити важливу роль у поширенні публічних зібрань.

Виклад основного матеріалу. Мистецькі приватні колекції в Україні, зокрема на Слобожанщині, складались зазвичай із живопису і графіки європейських мистців і були зібрані під час подорожей чи проживання власників за кордоном. Одне з таких зібрань належало Аркадію Миколайовичу Алфьо- 
Мельничук $\Lambda$. Оригінальна графіка в українських зіьраннях XIX ст. ...

рову (1815-1872) - землевласнику Харківської губернії, досліднику гравюри. Народився він у с. Попівка Сумського повіту Харківської губернії за різними даними у 1811,1812 чи 1815 рр. Утім у Державному архіві Харківської області в Родословній книзі дворянства Харківської губернії $є$ запис про Аркадія (народ. 1815), сина М. Ф. Алфьорова (ДАХО: арк. 42, 43), в якій все ж документально засвідченим $є 1815$ рік народження.

Аркадій Алфьоров виріс в особливому культурному середовищі, характерному для дворянських маєтків XIX ст. У них уже облаштовувались мистецькі галереї з портретами предків, архітектурно-пейзажними видами, західноєвропейським живописом і аркушами гравюри. Його батько Микола Алфьоров - архітектор; відомі також його акварелі й гравюри. Закінчивши навчання в одному 3 харківських пансіонів, А. Алфьоров мріяв, відповідно до своїх нахилів та обдарованості, про Академію мистецтв. Утім за бажанням батька, який мав значний вплив на формування особистості А. Алфьорова, та, згідно із соціальним станом, він навчався в 1832-1836 pp. в Імператорському харківському університеті на словесному відділенні юридичного факультету (Алфьоров, 2016: 62). Після закінчення університету він мав вступити на службу і зайнятись облаштуванням успадкованого маєтку, тому мрії про академію довелось відкласти. «Єдиною втіхою його було поповнення художніх знань і збирання картин, рисунків, і художніх видань, на що він не шкодував свого статку» (Черноволот, 1911: 6).

Колекція графіки А. Алфьорова пройшла кілька етапів створення. Почав іï формування просвітитель і літератор, сумський архітектор-любитель О. Паліцин, засновник «Попівської академії» (гурток, який об'єднував передову дворянську інтелігенцію Слобожанщини), перебуваючи на службі в Петербурзі наприкінці XVIII ст. Колекція зберігалася в маєтку «Попівка» Сумського повіту Харківської губернії. Відомо, що саме батько Алфьорова іiі поповнював за дорученням Паліцина, виїжджаючи за кордон до Турції, Греції, Італії, Франції з метою вдосконалення майстерності, а також знайомства з видатними пам'ятками архітектури та мистецтва. Згодом він успадкував маєток і колекцію свого вчителя і друга.

Аркадій Алфьоров отримав колекцію вже від свого батька. Найбільші поповнення, а також упорядкування і вивчення колекції Алфьоров зробив, перебуваючи на лікуванні в Німеччині в 1856-1872 рр. (після падіння 3 коня отримав травму хребта). В Європі вже наприкінці XVIII ст. художній ринок склався в розгалужену комер- ційну систему 3 антикварними і книжковими крамницями (власники зазвичай були не лише комерсантами, а й великими любителями й знавцями), лотереями, видавництвом довідкових текстових і ілюстрованих покажчиків. Поширеною формою продажу творів мистецтва був аукціон. Тому А. Алфьоров, незважаючи на хворобу, відвідував аукціони, знайомився з продавцями графіки і художниками в Берліні, Лейпцизі, Дрездені, Аахені, Бонні. «Усі галереї, кабінети і музеї я відвідую справно і суворо вивчаю усе гідне уваги», повідомляв він у листах до М. Зарудного, які друкувались у Додатках до Харківських губернських відомостей у 1859 р. (Рєдін, 1904: 82).

Безумовно, А. Алфьорова надихало на зібрання творів любов до мистецтва, враження від побачених за кордоном приватних колекцій і картинних галерей, але метою створення колекції стало й розуміння важливої ролі мистецтва у вихованні й освіті. Високий рівень власної освіти і культури, знайомство 3 письменником Г. КвіткоюОснов'яненком, засновником Харківського університету В. Каразіним, спогади батька про О. Паліцина і «Попівську академію»- усе це сприяло думці розмістити власну галерею в Харкові.

Комплектуючи свою колекцію графіки, Алфьоров намагався зібрати найвизначніші роботи в цій галузі мистецтва. Колекціонування Алфьоров розглядав як служіння високій меті. «Потрібно мені самому створити собі рід служби, на якій би я міг діяльно трудитися і принести користь батьківщині. Якщо я влаштую музеум, це почасти загладить провину мою, що я вбив талант свій, 3 яким би міг зробити щось», - писав А. Алфьоров у листі з Аахена 1858 р. (Редін, 1904: 83). 3 листа стає зрозумілим, що пожертвувати свою колекцію університету Алфьоров задумав ще тоді. Тому i формування іiі мало на меті давати уявлення про розвиток європейського мистецького процесу, національні школи та стилі, творчість митців, що надало їй просвітницького характеру.

У 1873 р. після смерті А. Алфьорова (похований у Бонні) за його заповіту зібрання творів мистецтва - 421 аркуш оригінальної графіки, 50 живописних картин нідерландських та голландських художників XVII ст., близько 3000 гравюр та 164 книги 3 мистецтва - надійшло до Музею університету.

А. Алфьоров уособлював тип колекціонера, який не лише збирав твори мистецтва, але й досліджував їх, невтомно поповнюючи власні знання. Колекція оригінальної графіки Алфьорова була поділена по п'яти портфелях згідно з часом створення: у двох - 204 твори XVI-XVIII ст., у трьох - 
217 творів XIX ст. Оригінальну графіку і гравюру 3 огляду на їі чутливість до світла зберігали в особливих умовах, здебільшого в папках (портфелях). Майже всі твори в колекції мають підписи митців або старовинні позначки колекціонерів про авторів, що наглядно демонструє високий рівень і систему відбору творів до колекції. Алфьоров не надавав перевагу певному стилю, жанрам чи національній школі. Його метою було створення цілісного уявлення про еволюцію графічного мистецтва від епохи Відродження до сучасності.

Графічні твори російської школи художників були представлені лише XIX ст., у колекції їх було небагато - ескіз сепією Карла Брюллова, два малюнки олівцем I. Айвазовського, малюнок пером I. Шишкіна й деякі ін. Усе ж в XIX ст. у колекціонерів переважала зацікавленість європейським мистецтвом. Утім Алфьоров був першим слобожанським збирачем, у колекції якого з'явились твори вітчизняного мистецтва. Це були чотири картини I. Айвазовського, з яким колекціонер підтримував дружні стосунки під час проживання художника в Харкові в $1850-\mathrm{x}$ рр.

Особливу увагу привертає зібрання голландського малюнка (близько 50 творів), яке вважається одним із найкращих в Україні. У малюнках XVII ст. знайшли відображення характерні риси голландського мистецтва періоду його «золотого віку». Їх поєднує 3 живописом загальне коло демократичних тем і народних образів, але в графіці ще більше відчутне переважання сюжетів, узятих з оточуючої дійсності.

Аркуші мають самостійний характер або є підготовчим матеріалом для майбутніх картин, вони невеликого формату, відрізняються стриманістю і камерністюформи.Простай сама техніка, ретельно продумана мистцями. Майстерно використана ними м'якість олівця, сепії, туші, акварелі для передачі загального характеру голландської природи - ії неяскравого освітлення, вологого повітря.

Зібрання А. Алфьорова дає уявлення про майстерність голландських мистців, які відкрили красу оточуючого світу, повною мірою акцентували на зображеннях природи, людини, тварин, світу речей. Уважне вивчення оточуючого призвело до низки значних художніх завоювань в області перспективи, передачі матеріалів, освітлення, атмосфери, водної стихії.

Один із ранніх малюнків «Сільський краєвид» (олівець, туш) найбільшого гарлемського художника Пітера Молейна, який спеціалізувався в жанрі пейзажу і разом 3 Яном ван Гойєном («На ковзанці» (олівець, туш, пензель) визначив шлях розвитку голландського реалістичного пейзажу 3 типовим зображенням низини, річки посеред піщаних берегів або сільської місцевості з дорогою поміж пагорбами. У Молейна немає відстороненого замилування природою, це конкретні пейзажі, оживлені рухливими фігурами людей.

Пейзажі Яна Лівенса, живописця і графіка, друга Рембрандта належать до кращих зразків жанру в голландському мистецтві. Лівенс перейняв прийоми світлотіні у Рембрандта, свідченням цьому є сепія «Фургон у дорозі» (сепія, пензель, перо), якій притаманні м'якість тональних переходів і трепетність штриха. До XVII ст. належать пейзажі Алберта Кейпа «Ліс» (олівець, акварель), Віллема ван де Велде «Морський пейзаж» (туш, сепія, пензель, перо), Алларта Евердінгена «Пейзаж 3 вівцями» (сепія, пензель), Ісаака де Мушерона «Лісовий краєвид» (олівець, акварель) і роботи жанристів Корнеліса Сафтлевена («Селянка коло діжки» (туш, сепія, пензель, перо), Йоханеса Леманса («Тераса 3 двома павичами» (туш, сепія, пензель, перо).

Голландська графіка XIX ст. різниться за жанрами і темами. Багато 3 художників, представлених у колекції, були сучасниками Алфьорова. Центром розвитку в голландському мистецтві цього часу стала Гаага, в якій працювали Йоганнес Босбоом («Внутрішній вигляд церкви» (акварель)), Віллем Рулофс («Біля струмка» (сепія)), Антон Мауве («Корови на водопої» (сепія, пензель)). Типовими анімалістичними сценками представлені Ян ван Равенсвей «Ферма» (сепія) і Симон ван ден Берг «Краєвид 3 вівцями» (сепія, пензель, перо). Пейзаж, один $з$ улюблених жанрів голландського мистецтва, домінував у творчості Антона Браакмана «Зимовий краєвид» (туш, сепія, пензель), Андреаса Схельфхаута «Краєвид 3 вітрильником» (сепія, пензель), Хермана Куккука «Морський краєвид» (сепія, пензель). До жанристів належать Пітер Герард Вертін «Базар» (акварель). Акварель «Букет квітів» Георгіуса Яна ван Оса позначена віртуозністю виконання і свіжістю вражень від натури. Своєю творчістю він підтверджує, що високий рівень майстерності натюрморту, набутий у «золоту добу» голландського мистецтва, зберігається й надалі протягом XVII-XIX ст.

Один із найцінніших творів у колекції акварель «Смерть рибалки» Йозефа Ізраельса, який сприйняв багато зі спадщини великого художника-гуманіста Рембрандта. Робота поєднує глибокий психологізм із природною побудовою композиції, узагальненням образів. У техніці акварелі виконані роботи «Осінній краєвид» Яна Хоппенброуверса, «За прядкою» Давида Йозефа Блеса, «Виганяння корів на пасовище» Хендріка Герріта тен Кате. 
Мельничук $\Lambda$. Оригінальна графіка в українських зіьраннях XIX ст. ...

Авторами більшості рисунків італійської школи графіки в колекції Алфьорова є відомі художники епохи Відродження, які доклали багато зусиль для збагачення видів рисунку, його стилістичних і технічних можливостей, поступово надаючи дедалі більшого значення рисунку як самостійному виду мистецтва. На відміну від збірки голландського мистецтва, у формуванні якої Алфьоров керувався насамперед ідеєю представити різноманітність жанрів у цій національній школі, у збірці італійської графіки колекціонер намагався зібрати якнайповніше представництво художніх шкіл. До римської школи XVI ст. належать Джуліо Романо і Полідоро да Караваджо, які працювали в майстерні Рафаеля і зазнали його впливу. Композиція «Полювання на оленів» (туш, сепія, білило, пензель) Д. Романо розкриває його як талановитого автора міфологічних сюжетів. Монохромна композиція «Принесення дарів» (туш, пензель) П. да Караваджо, яка наслідувала античним рельєфам, слугує прикладом техніки «сграффіто», що нагадує гравірування по штукатурці.

Малюнок венеціанського художника епохи Відродження Джіроламо Муціано «Відвідування св. Антонієм Павла-пустельника» (бістр, пензель, перо) позначено рисами монументальності, узагальненою трактовкою форм і врівноваженістю композиції. Талановитий рисувальник генуезької школи Лука Камбьязо (ескіз «Воскресіння Христа» (туш, перо, пензель) цікавий намаганням виявити стереометричні основи живих форм, в якого окремі частини тіла перетворювались на кубістичні паралелепіпеди. Учень знаменитого Гірландайо Бернардіно Почетті (Барбателлі), який працював у фресковому живописі, втілив кращі риси флорентійської школи. Його малюнок «Анна та Марія з немовлям Христом» (бістр, пензель. перо) виконаний м'яким і живописним штрихом, що покликаний підкреслити пластичну виразність.

У колекції присутні низка творів видатних мистців Італії. До пармської школи належить один із найбільших представників італійського маньєризму - Франческо Маццоло Парміджаніно, який створив рафінований аристократичний ідеал грації і краси. Спокійний, закінчений характер має його малюнок «Фігура жінки» (олівець, сепія, білило), в якому художник створює ліричний і вишуканий образ. Робота цікава й печаткою в лівому куті твору, що свідчить про попереднього власника графа Моріца фон Фріза. Це так званий власницький знак збирачів, регулярно вживаний та обов'язковий у більшості європейських країн (за такими знаками можна простежити походження й побутування твору). Акварель неві- домого художника XVI ст. «Диспута» 3 фрески Рафаеля також має власницький знак колекціонера і торговця естампами П'єра-Жана Маріетта.

Видатне ім'я в колекції - майстер болонського академізму Аннібале Караччі, один із засновників Болонської академії. У його легкому, ескізному начерку «Мадонна 3 покривалом» (бістр, перо) відчувається урочистість у трактовці сюжету.

Найвідомішому майстрові італійського бароко, 3 ім'ям якого пов'язаний розквіт венеціанського живопису й рисунку XVIII ст. Джованні Тьєполо належить ескіз плафонного розпису (олівець, сепія, пензель, перо), виконаний у характерній манері - легкими розпливчастими плямами сепії і нервової лінії пера. Зображенню сцен із народного життя присвячена акварель «Жінка 3 корзиною та двоє мисливців» відомого художника XIX ст. Бартоломео Пінеллі.

Оригінальна графіка німецької школи представлена рисунками та акварелями німецьких художників XVII-XIX ст. двох найбільших художніх центрів - Мюнхена і Дюссельдорфа. Зібрані твори виконані в різних техніках: акварель, олівець, туш, сангіна і представляють різні напрями в мистецтві: класицизм, романтизм, бідермаєр, реалізм тощо. Наявність у колекції Алфьорова численних малюнків німецьких художників пояснюється й місцем проживання збирача - у Бонні.

У цій частині зібрання - малюнки художників XVII ст.: сангіна Йоганна Генріха Рооса «Біля фонтану», яка створює враження начерку з натури, та трепетний, живописний, овіяний романтичним настроєм, малюнок олівцем «Біля моря» художника-пейзажиста Йоганна Фрідріха Тіле. Підвищена драматична виразність образу вирізняє роботу ЙоганнаГретлера «Святий Павло» (сангіна,крейда).

Найчисельніша група художників XIX ст., презентована в колекції, пов'язана з Дюссельдорфською школою. До відомих митців цієї школи належать Бенджамін Вотье («Монахи», акварель 3 анекдотичним мотивом сільського життя в сентиментальному дусі), Андреас Ахенбах («Пастухи зі стадом» (туш, сепія, пензель), Каспар Непомук Шеурен («Титул до видання про Венецію»(акварель, туш, пензель, перо). Досить велику групу в колекції становлять рисунки художників-жанристів Адольфа Вернера, Хайнріха Ріттера, Отто Кнілле та ін. Двома протилежними за настроєм і манерою виконання пейзажами показано в колекції мюнхенського художника Теодора Вергаса: «Гірський вид» і «Лісовий пейзаж» (сепія). Анімалістичні сценки характерні для творчості Вільгельма Кобелля - «Коні на водопої», «Корови на березі річки» (олівець). 
У колекції Алфьорова є кілька «колекцій в колекції», що відрізняються не лише кількістю творів, але й дозволяють у повному обсязі ознайомитись із творчістю мистця. Такою є збірка графіки Йогана Адама Клейна - 700 творів (акварелі і гравюра). Клейн - учасник походів 1813-1814 pp., який багато звертався до зображень військового побуту, епізодів військових подій. В акварелі «Військовий візок» із фотографічною точністю зображено елементи військової амуніції, коней. На пейзажах Клейна - природа різних країн, багато творів присвячені Нюрнбергу та його околицям, місту, де жив художник («Колодязь у Доренбасі», «Замок Грейффенштейн на Дунаї» (акварель)). Героями його жанрових композицій були сучасники («Молочник в Альпах» (акварель)); талант мистця проявився також у портретному жанрі, зображенні тварин і птахів («Краєвид 3 конем» (акварель)). Цілісні монографічні колекції зазвичай можна було придбати на аукціонах.

Французька графічна школа показана сангінами відомого скульптора Едма Бушардона «Апостол Павло», «Спокуса св. Антонія», акварелями Панкраса Бесса «Червоний тюльпан», «Жовта груша», «Зелена груша».

Серед митців інших країн, представлених у колекції, найвідомішими $є$ австрійський художник Август Петенкоффен («Хлопчик із глечиком» (олівець, акварель)), данський скульптор Бертеля Торвальдсена (малюнок «Карітас»), бельгійський митець Шарля Анрі-Жозефа Лейкерта («На березі моря» (сепія, пензель)).

Збірка оригінальної графіки стала основою цього розділу в зібранні університетського музею в Харкові. Музей відвідували не лише студенти, а й усі охочі три рази на тиждень, а також учні художньої школи М. Раєвської-Іванової і численних приватних студій, що створювались художниками наприкінці XIX ст.

Вважається, що частина колекції А. Алфьорова була втрачена у Другу світову війну. 3 утраченого - рисунки Я. Брейгеля Бархатного, А. Саккі, А. ван Дейка, Й. Б. Лампі. Утім, авторкою статті на основі аналізування записів в інвентарних книгах Української картинної галереї встановлено, що напередодні війни кількість творів із колекції Алфьорова не відповідала початковому значенню. На 1934 р. задокументовано наявність лише 125 робіт оригінальної графіки (за заповітом надійшла 421 робота). Вірогідна їхня втрата у період революційних подій або під час музейних реорганізацій у 1920-1930-х рр. Також твори могли бути вилучені з музеїв задля поширеної практики продажу за кордон. На жаль, досте- менних документальних підтверджень цим припущенням нині не знайдено. Під час війни твори 3 колекції Алфьорова, як і загалом зібрання Української картинної галереї, знаходились в евакуації у Красноярську, Абакані, згодом у Новосибірську у сховищах евакуйованої Третьяковської галереї (Мизгіна, 2005: 34, 35).

Нині твори мистецтва 3 колекції Алфьорова зберігаються в Харківському художньому музеї більше 100 аркушів оригінальної графіки, близько 2000 гравюр, 17 живописних робіт (Прокатова, 2005: 68). Кілька творів живопису з колекції перерозподілили після війни до Донецького художнього музею, Алупкінського музею-заповіднику, кілька стародруків зберігаються в науковій бібліотеці Харківського університету.

Колекція оригінальної графіки А. Алфьорова, незважаючи на втрати і переміщення, і нині становить основу зібрання зарубіжного мистецтва Харківського художнього музею і презентується на музейних виставках в Україні і за кордоном, найбільшими 3 яких були «Виставка малюнку й акварелі голландських художників XVIIXIX ст.» (1970, ХХМ), «Перші художні колекції Харкова» (1995-1997, ХХМ), «Голландський малюнок 3 Харківського художнього музею» (1998, США, Тафт музеум, Цинциннаті), «Мистецька скарбниця Слобожанщини» (1999, Український дім, Київ), «Слобожанський маєток: господарі й колекції» (2007, ХХМ), «Три сторіччя оригінальної голландської графіки XVII-XIX ст. 3 колекції XXM» (2017, Музей українського живопису, Дніпро), «Графіка Адама Клейна» (2018, Галерея АВЕК, Харків). Виставкові проєкти, в яких задіяні твори 3 приватної колекції А. Алфьорова, зумовили мистецтвознавчі пошуки, атрибуції, друк каталогів, буклетів та альбомів. Велика кількість творів із колекції оригінальної графіки А. Алфьорова репродукована в альбомі «Музейні скарби Харкова. Мистецтво Західної Європи та Сходу XV-XX ст.» (Мизгіна, Прокатова, Литовко, Мельничук, 2009).

Висновки. Колекція оригінальної графіки Аркадія Алфьорова $є$ вираженням естетичних смаків часу і особистих вподобань ії автора, його уявлень про мету і завдання колекціонування. Вона відрізняється якістю вибору, охопленням якнайбільшого матеріалу стосовно технік, шкіл, жанрів графічного мистецтва 3 метою демонстрації цілісної картини його розвитку. Увійшовши до складу університетського Музею красних мистецтв і старожитностей, вона сприяла розвитку мистецьких смаків, залученню до прекрасного у краї, віддаленому від європейських столиць, була наочним 
посібником для студентів і учнів художніх шкіл із вивчення історії мистецтва. Сучасники, які могли бачити ці колекції в повному обсязі (на відміну від нинішнього часу), оцінювали їх досить високо.
Ім’я Аркадія Алфьорова, людини широких інтересів, знавця і пристрасного збирача творів мистецтва, з великою подякою вже майже 150 років згадують на Слобожанщині.

\section{СПИСОК ВИКОРИСТАНИХ ДЖЕРЕЛ}

1. Алфьоров О. Старшинський рід Алфьорових: генеалогія, соціально-політичне та майнове становище слобідської гілки другої половини XVII-початку XX ст. Біла Церква : Видавець О. Пшонківський, 2009. 150 с.

2. Мизгіна В. Драма музейної колекції. Відлуння війни. Музейний альманах : наукові матеріали, статті, виступи, спогади, есе. Харків : Курсор, 2005. С. 29-38.

3. Музей изящных искусств и древностей Императорского Харьковского университета. Коллекция гравюр А. Н. Алферова / сост. Н. Черноволот. Харьков : Типография и литография М. Зильберберг и Сыновья, 1911. 289 с.

4. Мистецтво Західної Свропи та Сходу XV-XX ст. Із зібрання Харківського художнього музею / Мизгіна В., Прокатова Т., Литовко Т., Мельничук Л. Харків : Колорит, 2009. 188 с.

5. Прокатова Т. Значення колекції А. М. Алфьорова у формуванні зібрання західноєвропейського мистецтва ХХМ. Музейний альманах : наукові матеріали, статті, виступи, спогади, есе. Харків : Курсор, 2005. С. 68-72.

6. Редин Е. Музей изящных искусств и древностей Императорского Харьковского университета (1805-1905): к истории университета. Записки Императорского Харьковского университета. Харьков : Университетская типография, 1904. Кн. 3. С. 43-106.

7. Державний архів Харківської області (ДАХО). Ф. 14. Родословная книга дворянства Харьковской губернии. Ч. 3, Т. 1. Оп. 11. Од. зб. 3, Арк. 42, 43.

8. Таньчук Р. Искусство коллекционирования. Коллекционирование как форма культуральной активности / перевод с польск. Харьков : Издательство «Гуманитарный Центр», М. Григорьева, 2016. 372 с.

\section{REFERENCES}

1. Alforov O. Starshynskyi rid Alforovykh: henealohiia, sotsialno-politychne ta mainove stanovyshche slobidskoi hilky druhoi polovyny XVII-pochatku XX st. [The officers of the Alfiorov family: genealogy, socio-political and property status of the Sloboda branch of the second half of the XVII th - early XX th centuries]. Bila Tserkva : Vydavets O. Pshonkivskyi, 2009. 150 p. [in Ukrainian].

2. Myzghina V. Drama muzeinoi kolektsii. Vidlunnia viiny [Drama of the museum collection. Echoes of war]. Museum almanac: scientific materials, articles, speeches, memoirs, essays. Kharkiv : Kursor, 2005. pp. 29-38. [in Ukrainian].

3. Muzej izyashchnyh iskusstv i drevnostej Imperatorskogo Har'kovskogo universiteta. Kollekciya gravyur A. N. Alferova [Museum of Fine Arts and Antiquities of the Imperial Kharkov University. Collection of engravings by A. N. Alferov] / compiler N. Chernovolot. Kharkiv : Tipografiya i litografiya M. Zil'berberg i Synov'ya, 1911. 289 p. [in Russian].

4. Myzghina V., Prokatova T., Lytovko T., Melnychuk L. Mystetstvo Zakhidnoi Yevropy ta Skhodu XV-XX st. Iz zibrannia Kharkivskoho khudozhnoho muzeiu [Art of Western Europe and the East XV-XX centuries. From the collection of the Kharkiv Art Museum]. Kharkiv : Kolorit, 2009. 188 p. [in Ukrainian].

5. Prokatova T. Znachennia kolektsii A. M. Alforova u formuvanni zibrannia zakhidnoievropeiskoho mystetstva KHKHM [The significance of A. M Alferov's collection in the formation of the collection of Western European art of the KHKHM]. Museum almanac: scientific materials, articles, speeches, memoirs, essays. Kharkiv : Kursor, 2005. Pp. 68-72. [in Ukrainian].

6. Redin E. Muzej izyashchnyh iskusstv i drevnostej Imperatorskogo Har'kovskogo universiteta (1805-1905): k istorii universiteta [Museum of Fine Arts and Antiquities of the Imperial Kharkov University (1805-1905): on the history of the university]. Notes of the Imperial Kharkov University. Kharkiv : Unyversytetskaia typohrafyia, 1904. Part 3, pp. 43-106. [in Russian].

7. Derzhavnyi arkhiv Kharkyvskoi oblasti [Kharkiv State Archive of Kharkiv region]. Fund 14. Genealogical book of the nobility of the Kharkov P 3,V. 1. des. 11. st.u. 3, pp. 42, 43. [in Russian].

8. Tan'chuk, R. Iskusstvo kollekcionirovaniya. Kollekcionirovanie kak forma kul'tural'noj aktivnosti [The art of collecting. Collecting as a form of cultural activity] / translation from Polish. Kharkiv : Gumanitarnyj Centr, M. Grigor'eva, 2016. 372 p. [in Russian]. 